\title{
Monitoring Pembelajaran Konsep Learning By Playing And Playing For Learning Sebagai Peningkatan Kualitas Pendidikan Di TK
}

\author{
Ninik \\ TK Kristen Petra Kediri \\ ninikpurwani45@gmail.com
}

\begin{abstract}
Abstrak
Seringkali kita tidak sadar bahwa Usia Taman Kanak-kanak adalah rentang usia bermain, dimana pada usia tersebut mereka cenderung menggunakan motoric kasarnya untuk bergerak melakukan aktivitas yang tentu saja akan menghasilkan sesuatu yang menyenangkan karena tidak lepas dari sifat anak-anak yang cenderung bermain.Di sisi lain dalam dunia pendidikan, bahwa kebutuhan anak dimasa usia dini ini mereka juga harus belajar .Dan kita sebagai orang dewasa harus menyadari bahwa anak-anak adalah anak-anak, yang seharusnya Saat mereka belajar disertai dengan sebuah permainan dan saat mereka bermain tidak sadar kalau mereka sedang belajar. Proses pembelajaran pada hakekatnya adalah interaksi guru dengan murid dalam rangka kegiatan belajar mengajar kepada siswa untuk mencapai tujuan yang diharapkan.Dengan demikian belajar mengajar harus bernilai normatif yaitu mengandung nilai yang mampu mengubah tingkah laku anak didik.Proses interaktif edukatif melibatkan komunikatif aktif dua arah anak didik dan guru. Dalam hal ini memang anak dituntut untuk lebih aktif daripada gurunya dalam arti sikap ,mental dan perbuatannya. Guru hanya berperan sebagai pendamping dan fasilitator saja namun di dalam menyusun program pengajaran supaya relevansi dengan karakteristik dan kebutuhan anak usia Paud maka guru dapat mengacu pada beberapa pakar pendidikan sekaligus perkembangan anak. Dapat disimpulkan bahwa Teori Learning by Playing \& Playing for Learning sangat sesuai diterapkan di lembaga Taman Kanak-kanak. Belajar sambil bermain dan bermain seraya belajar merupakan teori yang mempunyai pengaruh positif pada perkembangan anak didik karena dunia anak adalah dunia bermain. Dengan demikian pembelajaran yang menyenangkan akan menghasilkan pertumbuhan dan perkembangan yang maksimal dalam dunia pendidikan yang diharapkan baik dari segi fisik motorik, bahasa, social emosional, intelektualnya, serta moral dan watak anak-anak didik kita.
\end{abstract}

Kata Kunci: Konsep Learning By Playing, Playing For Learning, Kualitas Pendidikan TK 


\section{PENDAHULUAN}

Di sekolah kuno murid hanya mendengarkan. It is made for listening. Menurut John Dewey yang dikutip oleh Muis Sad Iman dalam bukunya "Pendidikan Partisipatif" yang mengatakan bahwa keadaan seperti itu harus diubah .Anak harus bersama-sama menyelidiki dan mengamati sendiri,berfikir dan menarik kesimpulan sendiri,membangun dan menghiasi sendiri sesuai insting dan keinginan mereka.Tampaklah di sini anak belajar sambil bekerja dan bekerja sambil belajar.Inilah makna istilah learning by Doing yang dikendaki oleh John Dewey dalam do school.

Bagaimanakah dengan konsep pembelajaran anak usia dini di Taman Kanak-kanak ? dan sejauh manakah peran aktif guru sekaligus sebagai orang tua berkaitan dengan konsep learning by playing dan playing for learning di atas?

Menurut kak Seto Mulyadi (2006) psikolog anak menjelaskan bahwa anak adalah anak,anak bukan manusia dewasa mini,karena itu metode pembelajaran terhadap anak harus disesuaikan dengan perkembangannya.Dunia anak adalah dunia bermain.Pada dasarnya anak senang sekali belajar asal dilakukan dengan cara-cara bermain yang menyenangkan.

Proses pembelajaran pada hakekatnya adalah interaksi guru dengan murid dalam rangka kegiatan belajar mengajar kepada siswa untuk mencapai tujuan yang diharapkan.Dengan demikian belajar mengajar harus bernilai normatif yaitu mengandung nilai yang mampu mengubah tingkah laku anak didik.Proses interaktif edukatif melibatkan komunikatif aktif dua arah anak didik dan guru.

Dalam hal ini memang anak dituntut untuk lebih aktif daripada gurunya dalam arti sikap ,mental dan perbuatannya. Guru hanya berperan sebagai pendamping dan fasilitator saja namun di dalam menyusun program pengajaran supaya relevansi dengan karakteristik dan kebutuhan anak usia Paud maka guru dapat mengacu pada beberapa pakar pendidikan sekaligus perkembangan anak.

(Khalifah Fil Ardi) "Belajar bagi kehidupan menjadi bagian yang sangat penting,karena manusia diciptakan sebagai pengelola dunia.Secara bertahap mereka akan mengalami fase pembelajaran yang didasarkan pada pengalaman ,sebagai ilustrasi terdekat adalah bayi manusia yang dilahirkan,jika tidak mendapat bantuan dari manusia dewasa yang lain,tidak belajar niscaya binasalah ia.

Uraian tersebut merupakan proses internal yang melibatkan ranah kognitif,afektif dan psikomotorik. Sedangkan kompleksitas belajar dapat dipandang dari dua subyek yaitu dari siswa dan dari lingkungan sekolah.Guru dalam hal ini sebagai pendamping dan fasilitator dituntut untuk lebih kreatif inovatif buka mata dan buka telinga untuk meningkatkan dan menciptakan suasana pembelajaran yang menyenangkan bagi anak didik.

Di bawah ini contoh foto anak-anak belajar sambil bermain dan bermain seraya belajar dengan media permainan buatan guru.

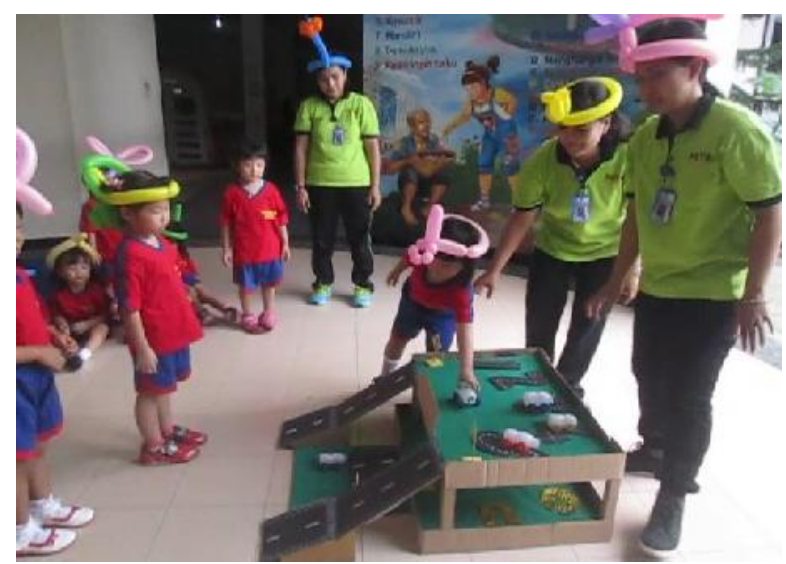

Menurut Maria Montessori Tokoh pendidikan anak usia dini, Montessori, mengatakan bahwa ketika mendidik anakanak, kita hendaknya ingat bahwa mereka 
adalah individu-individu yang unik dan akan berkembang sesuai dengan kemampuan mereka sendiri. Tugas kita sebagai orang dewasa dan pendidik adalah memberikan sarana dorongan belajar dan memfasilitasinya ketika mereka telah siap untuk mempelajari sesuatu. Masa ini juga masa yang paling penting dalam masa perkembangan anak, baik secara fisik, mental maupun spritual. Di dalam keluarga dan pendidikan demokratis orang tua dan pendidik berusaha memfasilitasi pertumbuhan dan perkembangan yang dibutuhkan oleh anak. Oleh karena itu, baik dan tepat bagi setiap orang tua dan pendidik yang terlibat pada proses pembentukan ini, mengetahui, memahami perkembangan anak usia dini.

Sebagian gambaran yang diberikan oleh Montessori tentang peran guru dan pengaruh lingkungan terhadap perkembangan kecerdasan sebagai berikut:

a. $80 \%$ aktifitas bebas dan $20 \%$ aktifitas yang diarahkan guru

b. melakukan berbagai tugas yang mendorong anak untuk memikirkan tentang hubungan dengan orang lain

c. menawarkan kesempatran untuk menjalin hubungan social melalui interaksi yang bebas

Pendapat Mantessori ini mendapat dukungan dari tokoh pendidkan Taman Siswa, Ki hadjar Dewantara, sangat meyakini bahwa suasana pendidikan yang baik dan tepat adalah dalam suasana kekeluargaan dan dengan prinsip asih (mengasihi), asah (memahirkan), asuh (membimbing). Anak bertumbuh kembang dengan baik kalau mendapatkan perlakuan kasih sayang, pengasuhan yang penuh pengertian dan dalam situasi yang damai dan harmoni.
Ki Hadjar Dewantara menganjurkan agar dalam pendidikan, anak memperoleh pendidikan untuk mencerdaskan (mengembangkan) pikiran, pendidikan untuk mencerdaskan hati (kepekaan hati nurani), dan pendidikan yang meningkatkan keterampilan.

Dapat disimpulkan bahwa Teori Learning by Playing \& Playing for Learning sangat sesuai diterapkan di lembaga Taman Kanak-kanak. Belajar sambil bermain dan bermain seraya belajar merupakan teori yang mempunyai pengaruh positif pada perkembangan anak didik karena dunia anak adalah dunia bermain ,menurut pendapat kak Seto Mulyadi.

Dengan demikian pembelajaran yang menyenangkan akan menghasilkan pertumbuhan dan perkembangan yang maksimal dalam dunia pendidikan yang diharapkan baik dari segi fisik motorik, bahasa, social emosional, intelektualnya, serta moral dan watak anak-anak didik kita.

\section{DAFTAR PUSTAKA}

Dewey, John. 2004. Experience and Education,alih bahasa John de Santo, Pendidikan dan Pengalaman, Penerbit: Kepel Press Yogyakarta

Dewantara, Ki Hajar. 1961. Bagian Pertama: Pendidikan. Jogjakarta: Madjelis Luhur Persatuan Taman Siswa

Mulyadi, Seto. -. Psikologi Pendidikan: dengan Pendekatan Teori-teori Baru dalam Psikologi.

Montessori, Maria. -. From Childhood To Adolescence (Dari Masa Kanak-kanak ke Masa Remaja). 